\title{
Evaluation of Elements Uptake in Soil and Different Plants
}

\author{
L. Várallyai ${ }^{1}$, B. Kovács ${ }^{2}$ \\ ${ }^{1}$ Institute of Applied Informatics and Logistics, Faculty of Economics and Business, University of Debrecen, \\ Hungary \\ ${ }^{2}$ Institute of Food Science, Quality Assurance and Microbiology, Faculty of Agricultural and Food Sciences \\ and Environmental Management, University of Debrecen, Hungary
}

\begin{abstract}
The applied informatics undergone a significant development at the end of XXth century, which is allowed analyzing of soil pollution by computer controlled system. On account of opening of the pollution we can process the experimental data fast and exactly so we can get such a large number of new information. The environmental pollutant affect of the molybdenum was studied by elements load experiment in Nagyhörcsök Experimental Station. The relation was analyzed between the uptake of molybdenum and other micro-elements and its effect on plant organs (loaf, seed) using by different statistical methods. The aim of our investigations to search for answers on how to arable crops respond to a possible soil contamination. It is also important to determine the extent of mobilized elements from the soil into the plants, which type of effect on them, and how leach the harmful substances into deeper layers (groundwater). A computer programme based on Visual C\# was developed to process of the large amount of data. The MySQL was applied to prepare the database, since we want to allow access to the newly developed database via internet technology. The data was filled up to the data tables mainly from the Excel tables. Data in internet-based databases must be properly protected. The program can provide access for two types of users at present: the database administrator who is authorised to do everything in connection with the database, and the user who is authorised to make queries only.
\end{abstract}

\section{Keywords:}

Multidisciplinary science, micro-elements, pollution, molybdenum, food chain, data-processing, Hungary.

\section{Introduction}

The informatics - especially applied informatics - undergone a significant development at the end of $\mathrm{XX}^{\text {th }}$ century. This is allowed analyzing of soil pollution by computer controlled system. The importance of this explains the soil is polluted especially by pesticides, wastes, nitrogen and phosphorus fertilizer (Bramryd, 2013), which through plants get into our food direct and indirect way (Brännval et al., 2014). In this way polluted foods can cause ill (Liu et al., 2013) in our vitally important organs (Patócs, 1990). On account of opening of the mentioned pollution we can process the experimental data fast and exactly so we can get such a large number of new information (Pais, 1990). Being aware of this valuable information we can make indispensable arrangements and we can hinder the impairing micro-elements - other elements as well - segregate in food chain (Marschner, 2012). The environmental pollutant affect (Rodrigues et al., 2012a \& 2012b) of the molybdenum was studied by elements load experiment in Nagyhörcsök Experimental Station. The relation was analyzed between the uptake of molybdenum and other micro-elements (Raguža et al., 2013) and its effect on plant organs (loaf, seed) using by different statistical methods (Adamo et al., 2014).

1. Experiment description in Nagyhörcsök experimental station

The trial was set up in Nagyhörcsök (Hungary) in 1991 on a calcareous chernozem soil formed on loess, containing $5 \% \mathrm{CaCO}_{3}$ and $3 \%$ humus in average in the ploughed layer. Soil texture is loamy with $20 \%$ clay and $40 \%$ fine fraction (Németh, Kádár, 2005).

Soil characteristics of the ploughed layer are: $\mathrm{pH}\left(\mathrm{KCl}\right.$ ): 7.3, AL- $\mathrm{P}_{2} \mathrm{O}_{5}$ (ammonium lactatesoluble $\mathrm{P}_{2} \mathrm{O}_{5}$ ): 80-100, AL- $\mathrm{K}_{2} \mathrm{O}$ (ammonium lactate-soluble $\mathrm{K}_{2} \mathrm{O}$ ): $140-160$, KCl-Mg: $150-180$, and $\mathrm{KCl}+$ EDTA soluble $\mathrm{Mn}, \mathrm{Cu}$ and $\mathrm{Zn}$ 
are $80-150,2-3$ and $1-2 \mathrm{mg} / \mathrm{kg}$, respectively (Jan et al., 2013).

The soil is well supplied with Mn, sufficiently supplied with $\mathrm{Mg}$ and $\mathrm{Cu}$, moderately supplied with $\mathrm{N}$ and $\mathrm{K}$, and weakly supplied with $\mathrm{P}$ and $\mathrm{Zn}$. The water table is at a depth of 13-15 m, which practically excludes its contamination by leaching. The climate is dry and the area is drought sensitive with 500-550 $\mathrm{mm}$ annual precipitation and negative water balance.

The applied treatments simulate soil contamination conditions that may occur in industrial areas, near highways, settlements and in city gardens. The 4 load levels $(0,90,270$ and $810 \mathrm{~kg}$ element $/ \mathrm{ha})$ were applied as a single dose in the spring of 1991 in the form of $\mathrm{AlCl}_{3}, \mathrm{NaAsO}_{2}, \mathrm{BaCl}_{2}$, $\mathrm{CdSO}_{4}, \mathrm{~K}_{2} \mathrm{CrO}_{4}, \mathrm{CuSO}_{4}, \mathrm{HgCl}_{2},\left(\mathrm{NH}_{4}\right)_{6} \mathrm{Mo}_{7} \mathrm{O}_{24}$, $\mathrm{NiSO}_{4}, \mathrm{~Pb}\left(\mathrm{NO}_{3}\right)_{2}, \mathrm{Na}_{2} \mathrm{SeO}_{3}, \mathrm{SrSO}_{4}$, and $\mathrm{ZnSO}_{4}$ (Kádár, 1995).

Fertilization was done yearly with 100-100-100 $\mathrm{kg} / \mathrm{ha} \mathrm{N}, \mathrm{P}_{2} \mathrm{O}_{5}$ and $\mathrm{K}_{2} \mathrm{O}$ active agents, in the form of ammonium nitrate, superphosphate, and potash fertilizers. The $13^{*} 4=52$ treatments with 2 replications were arranged in a split-plot design in altogether 104 plots.

Soils were sampled in 1993, 1996 and 2000 at the maximal depths of 60,90 and $290 \mathrm{~cm}$, respectively. In all cases the control and the maximal rate $(810 \mathrm{~kg} / \mathrm{ha})$ treatments were analyzed.

The samples were dried at $40^{\circ} \mathrm{C}$, homogenized and the ammonium acetate + EDTA-soluble element contents were analyzed by the method of Lakanen and Erviö (Lakanen, Erviö, 1971).

\section{Materials and methods}

The aims of the study were the determining the optimum measurement conditions for the content of elements for plant and soil samples and finding multielement measurement method to analyze the following elements (i.e: As, $\mathrm{Cd}, \mathrm{Mo}, \mathrm{Pb}$, and Se) and investigate (Månsson et al., 2012) the theoretical detection limit (approximately $1 \mathrm{ng} / \mathrm{kg}$ ), which is nowadays the best available value (Alloway, 2012). However, the measurement of real samples which showed an unexpected factor is greatly influenced the size of the intensity on the detector. At the time of analytical measurements could figure out that the carbon content of samples significantly depends on the size of the intensity of the same concentration. Therefore the signals is investigated on the various mass peaks (interferences). (Filep, Rékási, 2011). The investigations are carried out by different alcohols, such as C-containing solvents, this can be the reason of the above phenomenon.

\section{Sample preparation method to ICP-OES/MS}

Wet destruction sample preparation methods $\left(\mathrm{HNO}_{3}-\mathrm{H}_{2} \mathrm{O}_{2}\right)$ are used (Kovács et al., 2000) for the total element concentration determination of the plant and soil samples in the Central Laboratory of University of Debrecen. In case of higher concentrations - an Optima 3300 DV inductively coupled plasma optical emission spectrometer (ICP-OES, parameters are in Table 1.), in case of relatively lower concentrations, an inductively coupled plasma mass spectrometer (ICP-MS) (Thermo Elemental manufactured X7-type) are used to the analytical determination (O’Sullivan et al., 2013). The analyzed elements are 45.

\begin{tabular}{|l|l|}
\hline \multicolumn{2}{|l|}{ Inductive Coupled Plasma Optical Emission Spectrometer } \\
\hline Type: & OPTIMA 3300 DV \\
\hline Manufacturer: & Perkin-Elmer Ltd. \\
\hline Optical system: & Echelle-system, argon purged \\
\hline Range of wavelength: & $160-782 \mathrm{~nm}$ \\
\hline Detector: & Solid-state circuit detection, SCD \\
\hline Plasma monitoring: & Axial \\
\hline Type of nebulizer: & concentric (Meinhard Type A) \\
\hline $\begin{array}{l}\text { The type of peristaltic } \\
\text { pump: }\end{array}$ & black-black \\
\hline $\begin{array}{l}\text { Resolution } \\
\text { of the optical system: }\end{array}$ & Normal \\
\hline Resolving parameter: & $0.007 \mathrm{~nm}$ \\
\hline
\end{tabular}

Source: own processing

Table 1: The parameters of the ICP optical emission spectrometer.

ICP-MS technique (parameters are in Table 2.) was used to analyze the trace element contents (As, $\mathrm{Cd}, \mathrm{Mo}, \mathrm{Pb}$ and $\mathrm{Se}$ ) of the plants (Filep, Rékási, 2012). Inductively coupled plasma mass spectrometer (ICP-MS) was used for analyses for microelements due to $\mathrm{ppb}$ concentrations ( $\mathrm{ug} / \mathrm{kg}$ ). During analysis, collision and reaction gas $(\mathrm{CCT}=$ collisional cell technique $)$ was applied in order to reach the lower limit of detection of elements analyzed. 


\begin{tabular}{|l|l|}
\hline \multicolumn{2}{|c|}{ ICP-MS } \\
\hline Type: & Thermo Elemental X7 \\
\hline RF power output: & $1400 \mathrm{~W}$ \\
\hline Plasma gas flow rate: & $141 \cdot \mathrm{min}^{-1}$ \\
\hline Nebulizer flow rate: & $0.81 \cdot \mathrm{min}^{-1}$ \\
\hline Sample flow rate: & $11 \cdot \mathrm{min}^{-1}$ \\
\hline Pole Bias: & $-3.1 \mathrm{~V}$ \\
\hline Hexapole bias & $4.5 \mathrm{~V}$ \\
\hline Extraction & $-118 \mathrm{~V}$ \\
\hline Focus: & $3 \mathrm{~V}$ \\
\hline Analog detector: & $2500 \mathrm{~V}$ \\
\hline PC detector & $3850 \mathrm{~V}$ \\
\hline $\begin{array}{l}\text { CCT gas }\left(\mathrm{H}_{2}-\mathrm{He}, 7 \%-93 \%\right) \\
\text { flow rate }\end{array}$ & $5.9 \mathrm{~cm}^{3} \cdot \mathrm{min}^{-1}$ \\
\hline
\end{tabular}

Source: own processing

Table 2: The ICP-MS instrument settings and measurement parameters.

2. Conversion of the ICP-OES/MS measured data by excel macro

The ICP-OES/MS instrument averages the measured data and calculates the deviation for each element. The measured data have to be converted, rounded and placed into a table on the basis of a certain aspect for further processing. This process takes a long time in spite of the fact that a fixed Excel macro (http://www.excel-easy. com/vba.html) was available at the department. Processing of the databases takes at least one hour depending on the number of measured elements and samples.

3. The developer system and the database handling

New features are introduced in Visual Studio 2010
C\# that improve Microsoft Office programming (Heljsberg et al., 2010). Many computer users live in the Microsoft Office suite, using Excel as the core tools to perform the majority of their daily computer tasks. Enhancements in the .NET Framework 4 and Visual Studio 2010 make Office automation solutions easier than ever to write and deploy, in either Visual C\#. Visual Studio 2010 offers a number of Office templates. Choosing the Excel 2010 Workbook template opens a blank Excel workbook template that is the spreadsheet shown when the solution is run. The Excel programming can be started from this point in Visual Studio $\mathrm{C \#}$ environment (http://visualstudiomagazine.com/articles/2011/ 06/20/wcovb_automate-excel.aspx).

The MySQL (http://www.mysql.com) was applied to prepare the database, since we want to allow access to the newly developed database via internet technology. The data was filled up to the data tables mainly from the Excel tables. Data in internet-based databases must be properly protected. The program can provide access for two types of users at present: the database administrator who is authorised to do everything in connection with the database, and the user who is authorised to make queries only.

\section{Results and discussions}

\section{The developed programme}

The conversion of the measured data was carried out. The data was rounded and placed into table by using Microsoft Visual C\# 2010 (http://www. visualstudio.com) developing system (Fig. 1.), since its objects and programming opportunities provided more possibilities than an Excel macro.

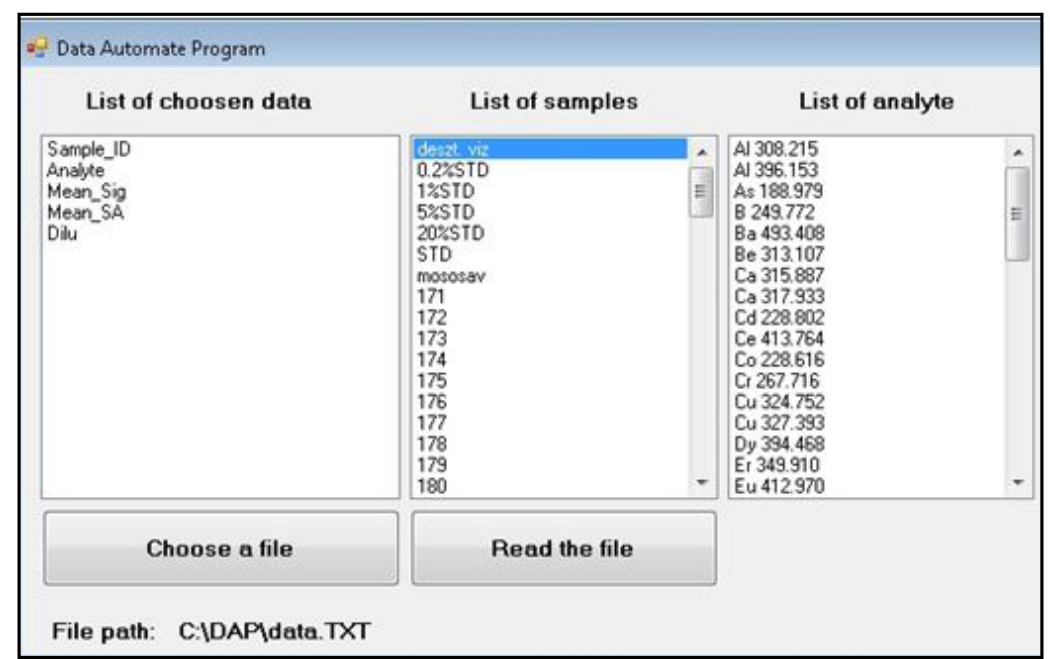

Source: own processing

Figure 1. Conversion and rounding measured data. 
The received figures was saved when running the program into an Excel worksheet in order to make further data processing easier (Fig. 2.).

The selected data file is shown in the first list. The CSV file headers (Sample ID, Analytical lines, average signal size, average standard deviation and dilution) were read and formed the selected data file by the programme. This can be seen in the first list (Fig. 1.).

The "sample ID" was read to the second list. Distilled water wash, the standard samples measurement and the acid washing is done before any samples. The first sample always comes after the acid washing.

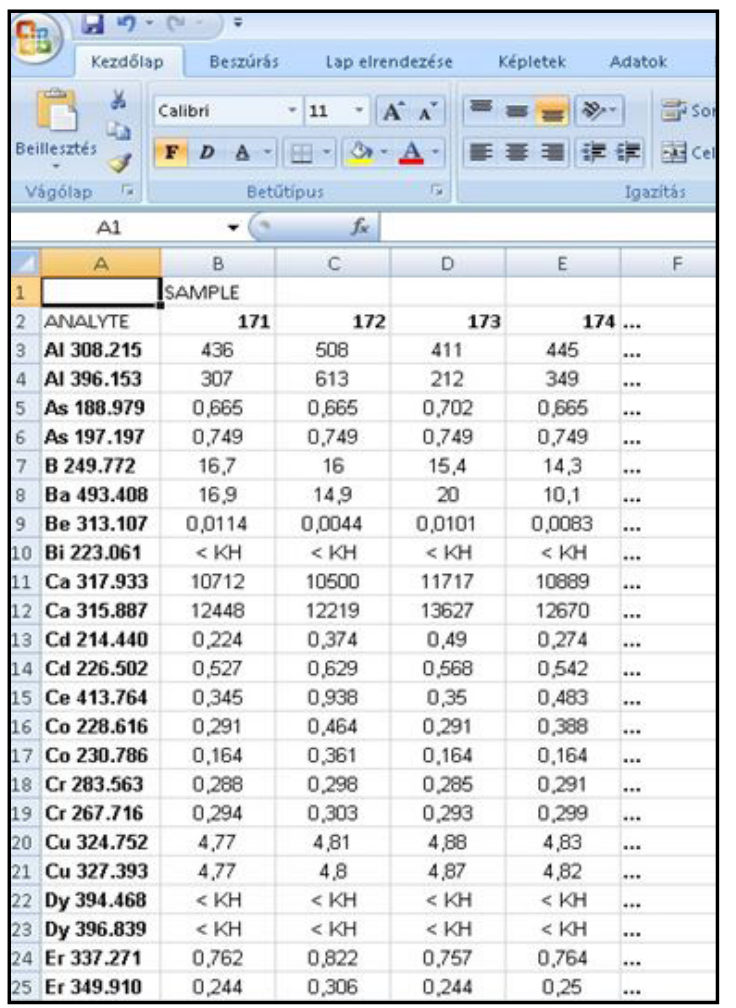

Source: own processing

Figure 2: Converted and rounded data exported to excel.

Various items analytical lines are visible in the third list. In case of ICP-OES/MS it is given, which item line can be measured most efficiently.

The saved figures exported into an Excel worksheet (Fig. 2.). This data are converted and rounded. The column headers are the sample_IDs, the row headers are the analytical lines. The " $<\mathrm{KH}$ " symbol meaning that under the detection limit.

\section{Storing the converted data in the MySQL database}

The next step is save these data into a database.

The central table is the "Element", where the chemical symbols and the measured microelement concentrations of the plant and plant part, the type of soil and how much dose the soil were treated, where the plant was grown are stored (Fig. 3.). It is important to store the year of the sampling.

The different plants, plant parts and the soil type are stored in the other three tables. In case of soil measurement is important to know which depth profile the soil derived from.

The major plants, which are investigated, the followings: carrot, maize, pea winter wheat, potato.

The plant parts are the followings: root, stem, leaf, bloom, and seed.

A stable relational database is also needed which will handle data and also provide data for the query system. Since the aims were applying standard solutions, we needed an SQL-based system and finally chose the MySQL database server (http://www.mysql.com), because it is free of charge, portable, compact and fast in case of bigger record numbers. Another gain, if we want to access these data through the Internet by a browser program, we can use this database system with the PHP server-side language efficiently, no need any conversion ( $\mathrm{Hu}$ et al., 2014).

Through the authorisation system, the authorisation level of each user can easily be determined. In case of database administrator authorisation, almost any kind of query can be made in connection with the database through the general query module (Tuya et al., 2007).

Special queries can be created to give the "Soil", the "Plant" and the "Plant_part", the "Sample year" and "Soil dose" parameters. Using these parameters the give element concentration value can be got and exported to Excel or SPSS to analyze the data by statistical method.

The first step is to test this new program. Two examples on the Fig. 4. and 5. can be seen for the molybdenum concentration changes (Anke, 2006) in the maize leaf and seed (Ráthonyi et al., 2010). The molybdenum treatment was 90,270 and $810 \mathrm{~kg} / \mathrm{hectare}$. 


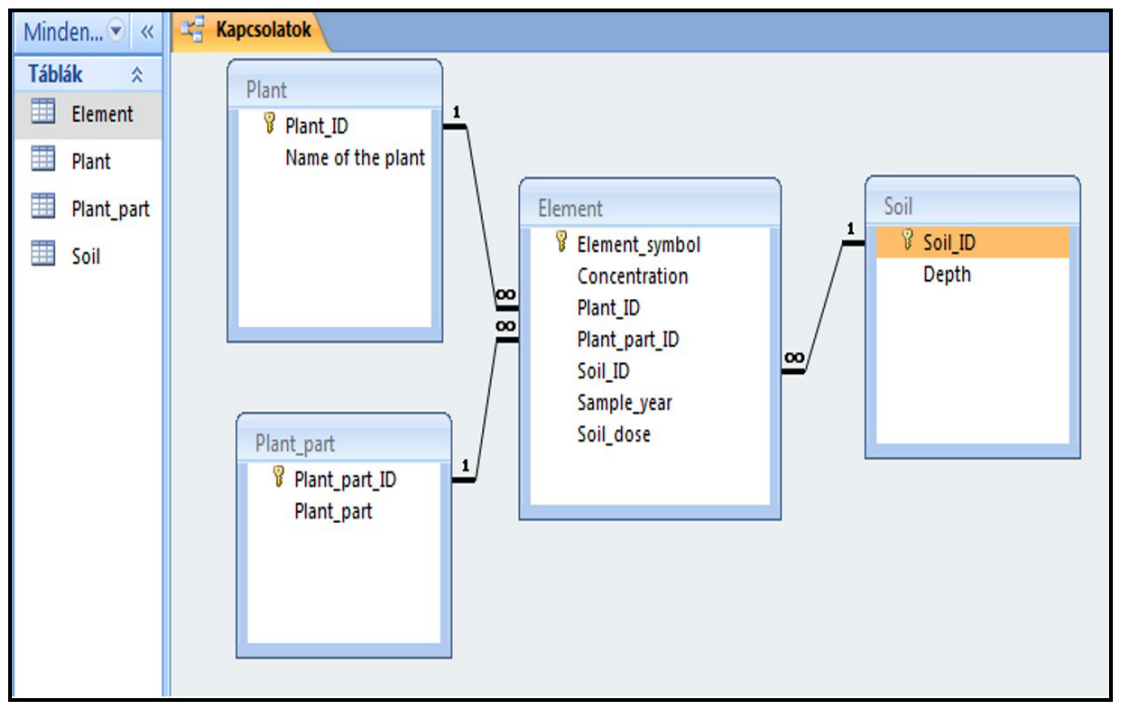

Source: own processing

Figure 3: Database schema.

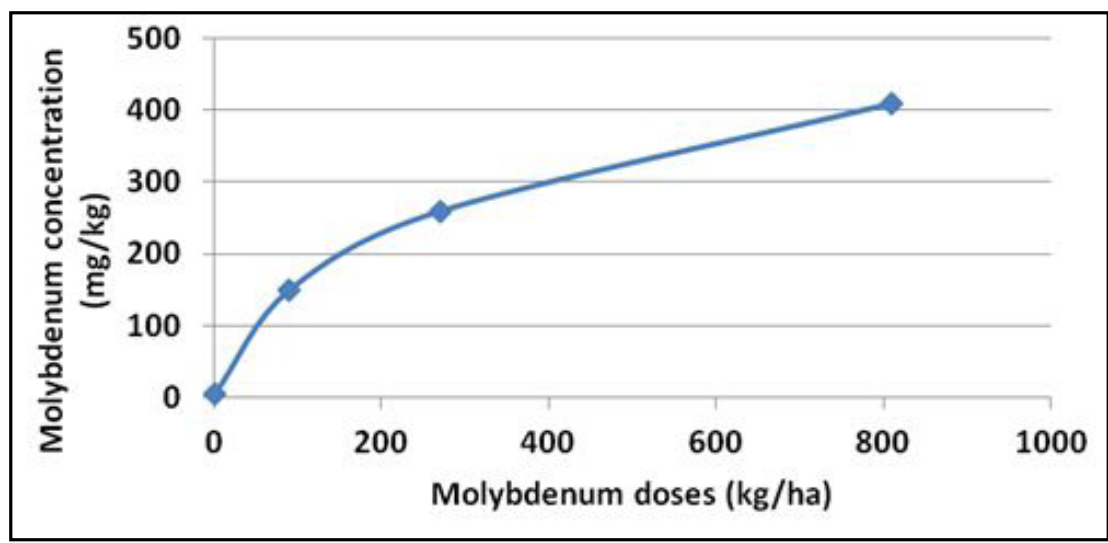

Source: own processing

Figure 4. Change of the molybdenum concentration of the maize leaf.

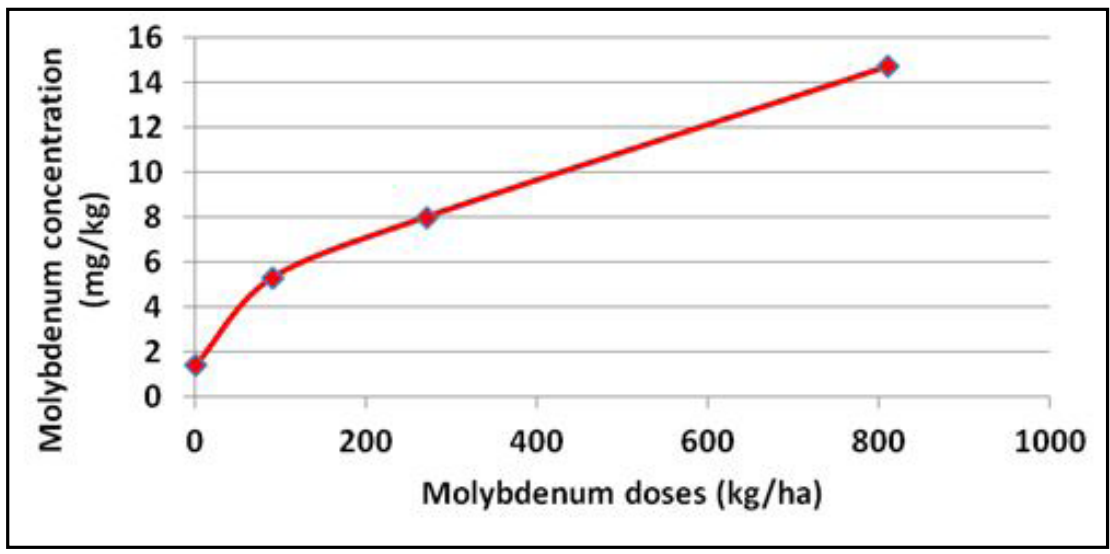

Source: own processing

Figure 5. Change of the molybdenum concentration of the maize seed. 


\section{Conclusion}

The conversion of the measured data was carried out. The data was rounded and placed into table by using Microsoft Visual C\# 2010 (http://www. visualstudio.com) developing system (Fig. 1.), since its objects and programming opportunities provided more possibilities than an Excel macro. The received figures was saved when running the program into an Excel worksheet in order to make further data processing easier. The column headers are the sample_IDs, the row headers are the analytical lines in the Excel worksheet.

The saved data was exported into a database. Since the aims were applying standard solutions, we needed an SQL-based system and finally chose the MySQL database server, because it is free of charge, portable, compact and fast in case of bigger record numbers. We have four tables. The central table is the "Element", where the chemical symbols and the measured microelement concentrations of the plant and plant part, the type of soil, how much dose the soil were treated, where the plant was grown are stored and the year of the sampling The different plants, plant parts and the soil type are stored in the other three tables.

This database is tested after created and filled up

Corresponding author:

László Várallyai, associate professor

Department of Economics, Faculty of Economics and Management,

University of Debrecen, Böszörményi út 138., Debrecen, H-4032, Hungary

E-mail:varal@agr.unideb.hu

\section{References}

[1] Adamo, P., Iavazzo, P., Albanese, S., Agrelli, D., De Vivo, B., Lima, A. Bioavailability and soil-to -plant transfer factors as indicators of potentially toxic element contamination in agricultural soils. Science of The Total Environment. 2014, Vol. 500-501, p. 11-22. ISSN: 0048-9697.

[2] Alloway, B. Heavy Metals in Soils Trace Metals and Metalloids in Soils and their Bioavailability, Third Edition. Springer. 2012, p. 525. ISBN 978-94-007-4469-1.

[3] Anke, M. Molybdenum - An essential and toxic element in the nutrition and environment of plants, animals and human beings. In: Szilágyi M., Szentmihályi K. (szerk): Trace elements in the food chain proceedings, International Symposium on Trace Element in the Food Chain, Budapest. 2006, p. 357-361. ISBN: 963-7067-132.

[4] Automate Microsoft Excel with Visual Studio 2010 [Online] Available: http://visualstudiomagazine. com/articles/2011/06/20/wcovb_automate-excel.aspx [ Accessed: 25 June 2014]

[5] Bramryd, T. Long-term effects of sewage sludge application on the heavy metal concentrations in acid pine (Pinus sylvestris L.) forests in a climatic gradient in Sweden. Forest Ecology and Management. 2013, Vol. 289, No. 1, p. 434-444. ISSN: 0378-1127. 
[6] Brännval, E., Nilsson, M., Sjöblom, R., Skoglund, N., Kumpiene J. Effect of residue combinations on plant uptake of nutrients and potentially toxic elements. Journal of Environmental Management. 2014, Vol.132, p. 287-295. ISSN: 0301-4797.

[7] Excel macros. [Online] Available: http://www.excel-easy.com/vba.html [Accessed: 20 March 2012].

[8] Filep, T., Rékási, M. Factors controlling dissolved organic carbon (DOC), dissolved organic nitrogen (DON) and DOC/DON ratio in arable soils based on a dataset from Hungary. Geoderma. 2011, Vol. 162, p. 312-318. ISSN: 0016-7061.

[9] Heljsberg, A., Torgersen, M., Wiltamuth, S., Golde, P. C\# programming language Fourth Edition, Boston, Addison-Wesley. 2010, p. 844. ISBN: 978-0-321-74176-9.

[10] Hu, Y., Callebert, P., Vandemoortel, I.,Nguyen, L., Audenaert, D., Verschraegen, L., Vandenbussche, F., Van Der Straeten D. TR-DB: An open-access database of compounds affecting the ethyleneinduced triple response in Arabidopsis. Plant Physiology and Biochemistry. 2014, Vol. 75, p. 128-137.

[11] Jan, J., Borovec, J., Kopáček, J., Hejzlar J. What do results of common sequential fractionation and single-step extractions tell us about $\mathrm{P}$ binding with $\mathrm{Fe}$ and $\mathrm{Al}$ compounds in non-calcareous sediments? Water Resource. 2013, 47, No. 2, p. 547-557. ISSN: 0097-8078.

[12] Kádár, I.A talaj-növény-állat-ember tápláléklánc szennyeződése kémiai elemekkel Magyarországon. Környezetvédelmi és Területfejlesztési Minisztérium - MTA Talajtani és Agrokémiai Kutató Intézete. Budapest. 1995. ISBN: 963-04-5362-2.

[13] Kovács, B., Prokisch, J., Győri, Z., Palencsar, A. J. Studies on soil sample preparation for inductively coupled plasma atomic emission spectrometry analysis. Communications in Soil Science and Plant Analyses. 2000, 31, p. 1949-1963. ISSN: 0010-3624.

[14] Kirby, J.K., McLaughlin, M.J., Ma, Y., Ajiboye B. Aging effects on molybdate lability in soils. Chemosphere. 2012, 89, No. 7, p. 876-883. ISSN: 0045-6535.

[15] Lakanen, E., Erviö, R. A comparison of eight extractants for the determination of plant available micronutrients in soil. Acta Agralia Fennica. 1971, 123, p. 223-232. ISSN: 0039-5595.

[16] Liu, X., Song, Q., Tang, Y., Li, W., Xu, J., Wu. J., Wang, F., Brookes, P.C. Human health risk assessment of heavy metals in soil-vegetable system: a multi-medium analysis. Science of the Total Environment. 2013, Vol. 463-464, p. 530-540. ISSN: 0048-9697.

[17] Månsson, N., Bergbäck, B., Sörme L. Phasing out cadmium, lead, and mercury. Effects on urban stocks and flows. Journal of Industrial Ecology. 2012, 13, p. 94-111. ISSN: 1530-9290.

[18] Marschner (Ed.), Marschner's Mineral Nutrition of Higher Plants (third ed.). Academic press/ Elsevier Ltd. 2012, p. 651. ISBN: 978-0-12-384905-2.

[19] MySQL ${ }^{\text {TM}}$-database. [Online] Available: http://www.mysql.com [Accessed: 07 Sept 2014].

[20] Németh, T., Kádár, I. Leaching of Microelement Contaminants: a Long-term Field Study. Z. Naturforsch. 2005, 60c, p. 260-264. ISSN 0939-5075.

[21] O'Sullivan, J. E., Watson, R. J., Butler, E. C. V. An ICP-MS procedure to determine Cd, Co, $\mathrm{Cu}, \mathrm{Ni}, \mathrm{Pb}$ and $\mathrm{Zn}$ in oceanic waters using in-line flow-injection with solid-phase extraction for preconcentration. Talanta. 2013, Vol. 115, p. 999-1010. ISSN: 0039-9140.

[22] Pais, I. The problematic of essentiality of trace elements. In: Pais I. (ed.): New result in the research of hardly known trace elements and their importance in the international geosphere-biosphere programme. Proceedings of the $4^{\text {th }}$ international symposium, University of Horticulture and food industry. 1990, Budapest p. 191-204.

[23] Patócs, I. Occurrence of heavy metals, toxic elements in the soils of Hungary. In: Pais I. (ed.): New result in the research of hardly known trace elements and their importance in the international geosphere-biosphere programme. 1990, Proceedings of the 4. international symposium, University of Horticulture and food industry Budapest. p. 19-30. 
[24] Raguža, V., Jarsjöb, J., Grolandera, S., Lindborgb, R., Avilaa R. Plant uptake of elements in soil and pore water: Field observations versus model assumptions. Journal of Environmental Management. 2013, Vol. 126, p. 147-156. ISSN: 0301-4797.

[25] Ráthonyi, G., Várallyai, L., Kovács, B. Molybdenum investigation in the food-chain by statistical method. Acta Agraria Kaposváriensis. 2010, Vol.14, No. 3, p. 323-333. ISSN: 1418-1789.

[26] Rékási, M., Filep, T. Fractions and background concentrations of potentially toxic elements in Hungarian surface soils. Environmental Monitoring and Assessment. 2012, Vol. 184, p. 532-542. ISSN: 0167-6369.

[27] Rodrigues, S.M., Pereira, M.E., Duarte, A.C., Römkens P.F.A.M. Derivation of soil to plant transfer functions for metals and metalloids: impact of contaminant's availability. Plant and Soil. 2012, Vol. 361, p. 329-341. ISSN: 1573-5036.

[28] Rodrigues, S. M., Pereira, M. E., Duarte, A. C., Römkens P. F. A. M. Soil-plant-animal transfer models to improve soil protection guidelines: a case study from Portugal. Environment International. 2012, Vol. 39, p. 27-37. ISSN: 0160-4120.

[29] Tuya, J., Cabal, M. J. S., de la Riva, C. Mutating database queries. Information and Software Technology. 2007, Vol. 49, No. 4, p. 398-4717.

[30] Visual Studio 2010. [Online] Available: http://www.visualstudio.com [Accessed: 12 May 2014]. 